\title{
Author Correction: Cryo-EM structure of the bacterial Ton motor subcomplex ExbB-ExbD provides information on structure and stoichiometry
}

Herve Celia (1), Istvan Botos, Xiaodan Ni, Tara Fox, Natalia de Val, Roland Lloubes, Jiansen Jiang (1) \& Susan K. Buchanan (1)

Correction to: Communications Biology https://doi.org/10.1038/s42003-019-0604-2, published online 4 October 2019.

In the original version of the published article, the caption to Figure 2e contained the following text that incorrectly referenced ExbB and an incorrect PDB code: "Ribbon representation of the solution structure of the ExbB soluble periplasmic domain (in green, pdb code $2 \mathrm{PDU})^{4}$ and ExbB-ExbD".

This has been replaced with the following corrected text: "Ribbon representation of the solution structure of the ExbD soluble periplasmic domain (in green, pdb code 2PFU) ${ }^{4}$ and ExbB-ExbD". The error has been corrected in the HTML and PDF versions of the article.

Published online: 09 November 2020

\footnotetext{
(c) Open Access This article is licensed under a Creative Commons Attribution 4.0 International License, which permits use, sharing, adaptation, distribution and reproduction in any medium or format, as long as you give appropriate credit to the original author(s) and the source, provide a link to the Creative Commons license, and indicate if changes were made. The images or other third party material in this article are included in the article's Creative Commons license, unless indicated otherwise in a credit line to the material. If material is not included in the article's Creative Commons license and your intended use is not permitted by statutory regulation or exceeds the permitted use, you will need to obtain permission directly from the copyright holder. To view a copy of this license, visit http://creativecommons.org/licenses/by/4.0/.
} 